\title{
PENGARUH MAKRO EKONOMI DAN FUNDAMENTAL BANK TERHADAP NON PERFORMING LOAN
}

(Studi Pada Bank Umum Swasta Nasional Devisa yang Terdaftar Di Bursa Efek Indonesia Periode 2012-2016)

\author{
Oleh:
}

\section{KARMILA AISYAH AHMADI MOH. AMIN \\ RISKI AMALIA MADI}

(Jurusan Manajemen Fakultas Ekonomi dan Bisnis Universitas Halu Oleo Kendari)

\begin{abstract}
ABSTRAK
Penelitian ini bertujuan untuk menguji secara empiris pengaruh makro ekonomi dan fundamental bank terhadap non performing loan pada bank. Penelitian ini diuji dengan tujuh variabel independen yaitu: nilai tukar, pertumbuhan gross domestic product, tingkat suku bunga (BI rate), loan to deposit ratio, return on asset, pertumbuhan kredit dan loan losses provision. Populasi penelitian ini adalah bank umum swasta nasional devisa yang terdaftar di bursa efek Indonesia yang berjumlah 44 bank. Dengan menggunakan teknik purposive sampling penulis memilih 10 bank sebagai sampel. Penelitian ini menggunakan analisis regresi berganda dengan panel data sebagai alat pengolahan data dengan menggunakan program eviews 9 .
\end{abstract}

Hasil penelitian menemukan bahwa nilai tukar dan pertumbuhan gross domestic product berpengaruh positif tidak signifikan terhadap non performing loan, loan to deposit ratio berpengaruh negatif tidak signifikan terhadap non performing loan, tingkat suku bunga (BI rate) dan loan losses provision bepengaruh positif signifikan terhadap non performing loan sedangkan return on asset dan pertumbuhan kredit berpengaruh negatif signifikan terhadap non performing loan.

Kata Kunci: nilai tukar, pertumbuhan gross domestic product, tingkat suku bunga (BI rate), loan to deposit ratio, return on asset, pertumbuhan kredit dan loan losses provision

\section{PENDAHULUAN}

Perbankan mempunyai peranan penting dalam perekonomian suatu negara. Bank merupakan lembaga keuangan yang memiliki fungsi intermediasi antara pihak yang kelebihan dana (surplus of fund) dengan pihak yang kekurangan dana (lack of fund).

Salah satu sumber pendapatan bank berupa bunga yang berasal dari penyaluran kredit ke masyarakat (dana pihak ketiga). Dalam menyalurkan kredit kepada masyarakat pihak bank tidak menutup kemungkinan akan mendapat risiko kredit. Karena tidak semua

kredit yang diberikan kepada nasabah dapat tertagih pada waktunya tapi ada juga kredit yang tidak lancar pelunasannya atau dapat digolongkan kredit bermasalah.

Fahmi (2011:104) mengatakan bahwa risiko kredit merupakan risiko yang disebabkan oleh ketidakmampuan para debitur dalam memenuhi kewajibannya sebagaimana yang dipersyaratkan oleh pihak kreditur. Risiko kredit pada bank di lihat dari non performing loan. Penyebab terjadinya NPL dilihat dari faktor kelemahan bank dalam menganalisis dan mengawasi penyaluran kredit yang diberikan dan faktor moral dimana pihak bank tidak menerapkan prinsip kehatihatian dan tidak menerapkan praktek perbankan yang tidak sehat.

NPL merupakan salah satu indikator dalam menilai kinerja fungsi bank, tingginya tingkat NPL menunjukkan kesehatan bank yang rendah karena banyak terjadi kredit bermasalah di dalam kegiatan bank tersebut. Bank Indonesia menetapkan ketentuan ukuran maksimal tingkat rasio NPL sebesar 5\%. Jika bank memiliki tingkat NPL melebihi 5\% maka bank dapat dikatakan mengalami kegagalan 
kredit. Kredit bermasalah yang besar dalam industri perbankan membawa dampak yang luas yang akan merugikan bank.

Non performing loan dipengaruhi oleh dua faktor yaitu faktor makro ekonomi dan mikro ekonomi. Faktor makro ekonomi yang mempengaruhi Non performing loan diantaranya adalah pertumbuhan gross domestic product (GDP), tingkat suku bunga. Dan faktor mikro ekonomi dilihat dari fundamental bank diantaranya return to asset (ROA), pertumbuhan kredit dan loan loss provission (Messai dan Jouini ,2013).

Penelitian-penelitian mengenai penyebab terjadinya non performing loan telah dilakukan oleh beberapa peneliti sebelumnya. Penelitian yang dilakukan Soebagio (2005) mengemukakan bahwa nilai tukar berpengaruh positif yang signifikan terhadap NPL. Berbeda dengan penelitian yang dilakukan oleh Washington (2014) mengemukakan bahwa nilai tukar berpengaruh negatif signifikan terhadap NPL. Sedangkan Rosita dan Musdolifah (2006) mengemukakan bahwa nilai tukar tidak berpengaruh terhadap NPL.

Penelitian yang dilakukan Ahmad dan Bashir (2013) mengatakan bahwa pertumbuhan GDP memiliki hubungan negatif terhadap NPL hal ini bertentangan dengan penelitian Beck et al., (2013) yang menemukan hubungan positif antara GDP dan kredit bermasalah.

Penelitian yang dilakukan Mada dan Arfinto (2015) mengemukakan bahwa tingkat suku bunga berpengaruh positif terhadap NPL. Hal tersebut bertentangan dengan penelitian Ahmad dan Bashir (2013) yang menyatakan bahwa terdapat pengaruh negatif antara tingkat suku bunga dengan NPL. Penelitian yang dilakukan oleh Barus dan Erik (2016) mengemukakan bahwa LDR berpengaruh positif signifikan terhadap NPL. Berbeda dengan penelitian yang dilakukan Mada dan Arfinto (2015) mengemukakan bahwa LDR berpengaruh negatif signifikan terhadap NPL.

Penelitian yang dilakukan Achmadi (2004) mengatakan bahwa ROA berpengaruh positif terhadap NPL. Berbeda dengan penelitian yang dilakukan Messai dan Jouini (2013) mengemukakan bahwa dampak ROA berpengaruh negatif signifikan terhadap NPL.

Penelitian yang dilakukan Khemraj dan Pasha (2009) mengemukakan bahwa pertumbuhan kredit berpengaruh positif terhadap NPL. Berbeda dengan penelitian yang dilakukan Andres dan Bonilla (2012) menyatakan bahwa pertumbuhan kredit tidak berpengaruh terhadap NPL.

Penelitian yang dilakukan Ozili (2015) yang menujukkan bahwa loan losses provision berpengaruh positif terhadap terjadinya NPL

Kajian penelitian ini menindaklanjuti saran yang diungkapkan Messai dan Jouini (2013) yang menyarankan menambahkan variabel makro ekonomi terkait dengan nilai tukar dan variabel fundamental bank terkait dengan likuditas. Likuiditas pada bank diproksikan dengan loan to deposit ratio yang mempengaruhi non performing loan.

Berdasarkan research gap (hasil penelitian terdahulu) dan fenomena yang telah dipapakarkan diatas maka penulis mengangkat judul "Pengaruh Makro Ekonomi dan Fundamental Bank Terhadap Non Performing Loan pada Bank Umum Swasta Nasional Devisa yang Terdaftar di Bursa Efek Indonesia periode 2012 sampai 2016."

\section{TINJAUAN PUSTAKA}

\subsection{Teori Risiko Kredit}

Hanafi (2009:165) mengatakan bahwa risiko kredit adalah risiko yang terjadi jika counterparty (pihak lain dalam transaksi bisnis) tidak bisa memenuhi kewajibannya. Di dalam menilai risiko kredit bank harus mempertimbangkan tiga hal yaitu : default probability, credit exposure, recovery rate.

\subsection{Signalling theory}

Signalling theory mengasumsikan bahwa terdapat asimetri informasi antara manajer dengan investor atau calon investor. Manajer dipandang memiliki informasi tentang perusahaan yang tidak dimilki oleh investor maupun calon investor. Teori pensinyalan menjelaskan alasan pentingnya perusahaan menyajikan informasi kepada publik (Wolk et al., 2006).

\subsection{Indikator Risiko Kredit \\ 2.3.1 Non Performing Loan}

Risiko kredit pada bank dilihat dari Non performing loan. Kredit bermasalah adalah kredit yang dapat menimbulkan persoalan, bukan hanya terhadap bank selaku lembaga pemberi kredit, tetapi juga terhadap nasabah penerima kredit (Mahmoedin, 2010:1). Siamat (2005) mengatakan bahwa penetapan kualitas kredit didasarkan pada penilaian yang 
dilakukan dengan menganalisis faktor prospek usaha, kinerja debitur dan kemampuan membayar.

Menurut ketentuan Bank Indonesia terdapat tiga kelompok kolektibilitas yang merupakan kredit bermasalah atau non performing loan (Kuncoro dan Suhardjono, 2002) sebagai berikut : kredit kurang lancar, kredit diragukan dan kredit macet.

Proses pemberian dan pengelolaan kredit yang baik diharapkan dapat menekan NPL sekecil mungkin. Artinya, tingginya NPL sangat dipengaruhi oleh kemampuan Bank dalam menjalankan proses pemberian kredit dengan baik serta dalam hal pengelolaan kredit, termasuk tindakan pemantauan (monitoring) setelah kredit disalurkan dan tindakan pengendaliaan bila terdapat indikasi penyimpangan kredit maupun indikasi gagal bayar (Djohanputro dan Kountur, 2007). Bank Indonesia menetapkan ketentuan ukuran maksimal tingkat rasio NPL sebesar 5\%.

\subsection{Faktor Makro Ekonomi}

\subsubsection{Nilai tukar}

Badar et al. (2013) mengatakan bahwa kurs adalah tingkat pertukaran satu mata uang dengan satu satu mata uang lain. Nilai tukar ditentukan oleh pasar valuta asing yang terus-menerus tetap dibuka selama 24 jam sehari kecuali akhir pekan yang terdiri dari berbagai jenis pedagang mata uang. Nilai tukar mata uang sebagian besar dipengaruhi oleh pertukaran barang modal dan jasa dalam perdagangan internasional. Penurunan mata uang lokal akan menghasilkan barang impor mahal yang menempatkan tekanan untuk membiayai kredit pedagang oleh bank komersial dan risiko kegagalan mengalami peningkatan.

\subsubsection{Gross domestic product}

Menurut Mc Eachern (2000:146) bahwa gross domestic product / GDP artinya mengukur nilai pasar dari barang dan jasa akhir yang diproduksi oleh sumber daya yang berada dalam suatu negara selama jangka waktu tertentu biasanya satu tahun. Terdapat dua jenis gross domestic product yaitu sebagai berikut (Mankiw, 2000) : 1) Nominal GDP (GDP nominal) merupakan GDP yang memperhitungkan nilai barang dan jasa berdasarkan pada harga berlaku. 2). Real GDP (GDP rill) merupakan GDP yang memperhitungkan nilai barang dan jasa berdasarkan pada harga konstan.

\subsubsection{Tingkat suku bunga (BI rate)}

Sukirno (1994:377) mengatakan

bahwa pembayaran atas modal yang dipinjam dari pihak lain dinamakan bunga. Bunga yang dinyatakan sebagai persentase dari modal dinamakan tingkat suku bunga. Berarti tingkat suku bunga adalah persentase pembayaran modal yang dipinjam dari lain pihak. Penentuan suku bunga di Indonesia pada biaya dana (cost of fund) maupun bunga kredit (lending rate) mengacu pada BI rate. BI rate ialah kebijakan yang dibuat oleh Bank Indonesia mengenai suku bunga, yang diumumkan di publik yang mencerminkan sikap kebijakan moneter.

\subsection{Fundamental Bank}

\subsubsection{Loan to deposit ratio (LDR)}

Kasmir (2012:319) mengatakan bahwa loan to deposit ratio untuk mengukur koposisi jumlah kredit yang diberikan dibandingkan dengan jumlah dana masyarakat dan modal sendiri yang digunakan.

Simorangkir (2004:147) mengatakan bahwa loan to deposit ratio merupakan perbandingan antara kredit yang diberikan dengan dana pihak ketiga, termasuk pinjaman yang diterima, tidak termasuk pinjaman sub ordinasi. Loan to deposit ratio mempunyai peranan yang sangat penting sebagai indikator yang menunjukkan tingkat ekspansi kredit yang dilakukan bank sehingga LDR dapat juga digunakan untuk mengukur berjalan tidaknya suatu fungsi intermediasi bank. Besarnya loan to deposit ratio menurut Peraturan Bank Indonesia maksimum adalah $92 \%$ dengan batas minimum 78\% (PBI Nomor 15/7/PBI/2013).

\subsubsection{Return on asset (ROA)}

Kasmir (2008:201) mengatakan bahwa return on assets (ROA) merupakan rasio yang menunjukkan hasil (return) atas jumlah aktiva yang digunakan dalam perusahaan. Semakin besar rasio ROA suatu bank maka akan semakin besar pula tingkat keuntungan yang dicapai bank tersebut dan semakin baik pula posisi bank tersebut dilihat dari sisi penggunaan aset, standar rasio ROA yang aman menurut bank Indonesia adalah berkisar antara $0,5 \%$ sampai dengan $1,25 \%$. 
Syamsuddin (2009:63) mengatakan bahwa ROA adalah pembandingan antara laba bersih setelah pajak dengan jumlah aktiva

\subsubsection{Pertumbuhan kredit}

Pertumbuhan kredit memperlihatkan peningkatan atau penurunan jumlah seluruh kredit yang dipinjam dari beberapa periode waktu atau bisa dalam bentuk persentase. Utari et al. (2012) menyatakan bahwa pertumbuhan kredit yang berlebihan dapat mengancam kestabilan ekonomi makro. Peningkatan kredit khususnya kredit konsumsi dapat memicu pertumbuhan permintaan aggregat diatas output potensial yang mengakibatkan perekonomian memanas. Selama periode ekspansi, sektor perbankan cenderung memiliki ekspektasi yang terlalu optimis pada kemampuan membayar nasabah dan akibatnya kurang hati-hati dalam memberikan kredit kepada golongan berisiko tinggi. Sebagai akibatnya terjadi penumpukan pinjaman yang berpotensi menjadi bad loan.

\subsubsection{Loan loss provision}

Loan loss provision dianggap sebagai mekanisme kendali atas pinjaman yang dianggap berpotensi "hilang". Salah satu teori yang berkaitan dengan hal tersebut adalah collateral yang merupakan salah satu bagian dari prinsip 5 c pemberian kredit. Collateral merupakan jaminan oleh calon debitur yang memungkinkan untuk disita oleh bank untuk mengantisipasi gagal bayar (kasmir, 2008). Konsep collateral sejalan dengan loan loss provision yang merupakan jaminan yang dibuat oleh bank sebagai antisipasi kredit bermasalah. Hal tersebut sejalan dengan loan loss provision dimana semakin tinggi jaminan maka kemungkinan kredit bermasalah semakin kecil. Jumlah loan loss provision ditentukan berdasarkan pada kualitas posisi portofolio pinjaman.

Pengaruh nilai tukar terhadap non performing loan (NPL)

Nilai tukar adalah perbandingan nilai tukar mata uang suatu Negara dengan mata uang Negara asing (Hasibuhan, 2005:14). Wikutama, 2010 (dalam Yulita, 2014) menjelaskan bahwa depresiasi home currency memberikan dampak terhadap pinjaman dalam valuta asing karena nilai pinjaman meningkat secara relatif sesuai dengan penurunan tersebut. Peningkatan jumlah kewajiban akan mengakibatkan penurunan kemampuan debitur dalam menyelesaikan pinjaman, bahkan dalam banyak kasus mengakibatkan peningkatkan NPL.

$\mathrm{H}_{1}$ : Nilai tukar berpengaruh positif signifikan terhadap non performing loan (NPL)

\section{Pengaruh GDP terhadap non performing loan (NPL)}

Menurut McEachern (2000:146) mengatakan bahwa gross domestic product / GDP artinya mengukur nilai pasar dari barang dan jasa akhir yang diproduksi oleh sumber daya yang berada dalam suatu negara selama jangka waktu tertentu, biasanya satu tahun.

Pertumbuhan GDP memperlihatkan peningkatan income individu juga peningkatan pada perusahaan, oleh karena itu kemampuan untuk membayar hutang (kredit) menjadi meningkat dan dampaknya NPL menurun. Sebaliknya penurunan GDP memperlihatkan income individu juga peningkatan pada perusahaan menjadi menurun sehingga kemampuan untuk membayar hutang (kredit) juga menurun dan NPL mengalami peningkatan (Ahmad dan Bashir, 2013).

$\mathrm{H}_{2}$ : GDP berpengaruh negatif signifikan terhadap non performing loan (NPL)

\section{Pengaruh tingkat suku bunga terhadap non performing loan (NPL)}

Sukirno (1994:377) mengatakan bahwa tingkat bunga adalah persentase pembayaran modal yang dipinjam dari lain pihak. Tingkat suku bunga mengacu pada BI rate.

Bofondi dan Ropele (2011) bahwa peningkatan suku bunga memperburuk kualitas dari pinjaman semakin tingginya bunga kredit membuat debitur semakin sulit membayarkan pinjamannya. Dengan demikian dapat diartikan bahwa semakin tinggi bunga yang dibebankan kepada debitur maka kemungkinan besar akan meningkatkan kredit bermasalah. Hubungan ini juga bisa dijelaskan dengan menurunnya kemampuan peminjam untuk memenuhi kewajibannya sehingga tingkat suku bunga berpengaruh positif signifikan terhadap kredit bermasalah.

$\mathrm{H}_{3}$ : tingkat suku bunga berpengaruh positif signifikan terhadap non performing loan (NPL) 
Pengaruh loan to deposit ratio (LDR) terhadap non performing loan (NPL)

Dendawijaya (2005) mengatakan bahwa LDR menggambarkan kemampuan bank membayar kembali penarikan yang dilakukan nasabah deposan dengan mengandalkan kredit yang diberikan sebagai sumber likuiditasnya. Semakin tinggi rasio ini semakin rendah pula kemampuan likuiditas bank, semakin besar kredit yang salurkan dibandingkan dengan simpanan masyarakat pada suatu bank membawa konsekuensi semakin besar risiko yang harus ditanggung oleh bank yang bersangkutan. Sehingga akan menyebabkan semakin besar pula kemungkinan terjadinya NPL.

Astrini et al. (2014) mengatakan bahwa semakin tinggi rasio LDR maka akan menyebabkan meningkatnya rasio NPL yang terjadi pada bank. Karena apabila bank memiliki LDR yang tinggi maka bank akan mempunyai risiko tidak tertagihnya pinjaman yang tinggi yang nantinya akan mengakibatkan terjadinya kredit bermasalah dan bank akan mengalami kerugian.

$\mathrm{H}_{4}$ : Loan to deposit ratio (LDR) berpengaruh positif signifikan terhadap non performing loan (NPL)

\section{Pengaruh return on asset terhadap non performing loan (NPL)}

Kasmir (2008:201) mengatakan bahwa ROA merupakan rasio yang menunjukkan hasil (return) atas jumlah aktiva yang digunakan dalam perusahaan.

ROA merupakan efisiensi dalam pemanfaatan aset dan menunjukkan seberapa besar pendapatan yang dihasilkan dari aset. Hal ini juga sesuai dengan hipotesis "bad management" pada penelitian Berger deYoung (1997) yang mengatakan bahwa praktik manajemen yang buruk akan berdampak pada laba mereka akibat persoalan efisiensi biaya yang dikeluarkan perusahaan serta kualitas kredit yang diberikan pada debitur. Praktik manajemen yang buruk tersebut dikarenakan para manajer yang tidak kompeten dalam menjalankan berbagai kegiatannya. Ketika mereka tidak memiliki keterampilan yang cukup dalam hal credit scoring, menilai agunan hingga pengawasan terhadap debitur, faktor-faktor kesalahan manajemen tersebut akhirnya meningkatkan NPL.
$\mathrm{H}_{5}$ : Return on asset (ROA) berpengaruh negatif signifikan terhadap non performing loan (NPL)

\section{Pengaruh pertumbuhan kredit terhadap non performing loan (NPL)}

Pertumbuhan kredit menujukkan peningkatan atau penurunan jumlah seluruh kredit yang dipinjam dari waktu ke waktu (biasanya dalam bentuk persentase).

Keeton (1999) dalam Ghosh (2015) menyatakan bahwa semakin cepat pertumbuhan kredit sebenarnya akan berimplikasi peningkatan kerugian kredit. Hal ini dapat pula terjadi karena ketika bank meningkatkan penawaran kreditnya, bank mencoba memberikan kelonggaran mengenai standar kredit, atau melakukan berbagai kecurangan lainnya, sehingga meskipun terkesan bank mampu menjalankan fungsi intermediasinya dengan baik karena kreditnya banyak tersalurkan, namun debitur yang tidak kompeten hanya akan membawa masalah kredit macet bagi bank yang bersangkutan.

$\mathrm{H}_{6}$ : Pertumbuhan kredit berpengaruh positif signifikan terhadap non performing loan (NPL)

Pengaruh loan loss provision (LLP) terhadap non performing loan (NPL)

Loan loss provision mencerminkan sikap umum sistem perbankan untuk mengendalikan risiko. Abid, et al (2014) menghubungkan variabel kualitas kredit ini ke dalam hipotesis "skimping" milik Berger de Young (1997). Dalam hal ini, meningkatnya CKPN kredit sebagai hasil estimasi besarnya risiko kredit yang meningkat akan membuat bank melakukan berbagai penghematan untuk menekan biaya operasional lainnya. Penghematan yang dilakukan para manager demi terlihat efisien, justru akan menimbulkan masalah jangka panjang. Terkait dengan penghematan biaya aktivitas pengkreditan, semakin biaya tersebut ditekan, maka bisa menjadikan kualitas kredit tersebut menurun pada akhirnya kualitas kredit yang rendah akan meningkatkan NPL. Selain itu meningkatnya LLP akan mengurangi laba bersih dari bank yang bersangkutan. Kebijakan menaikkan margin tentu akan dipertimbangkan meskipun pada akhirnya dapat meningkatkan peluang terjadinya kredit bermasalah yang lebih besar. 
$\mathrm{H}_{7}$ : Loan loss provision (LLP)

berpengaruh positif signifikan terhadap non

performing loan (NPL)

KERANGKA KONSEP PENELITIAN

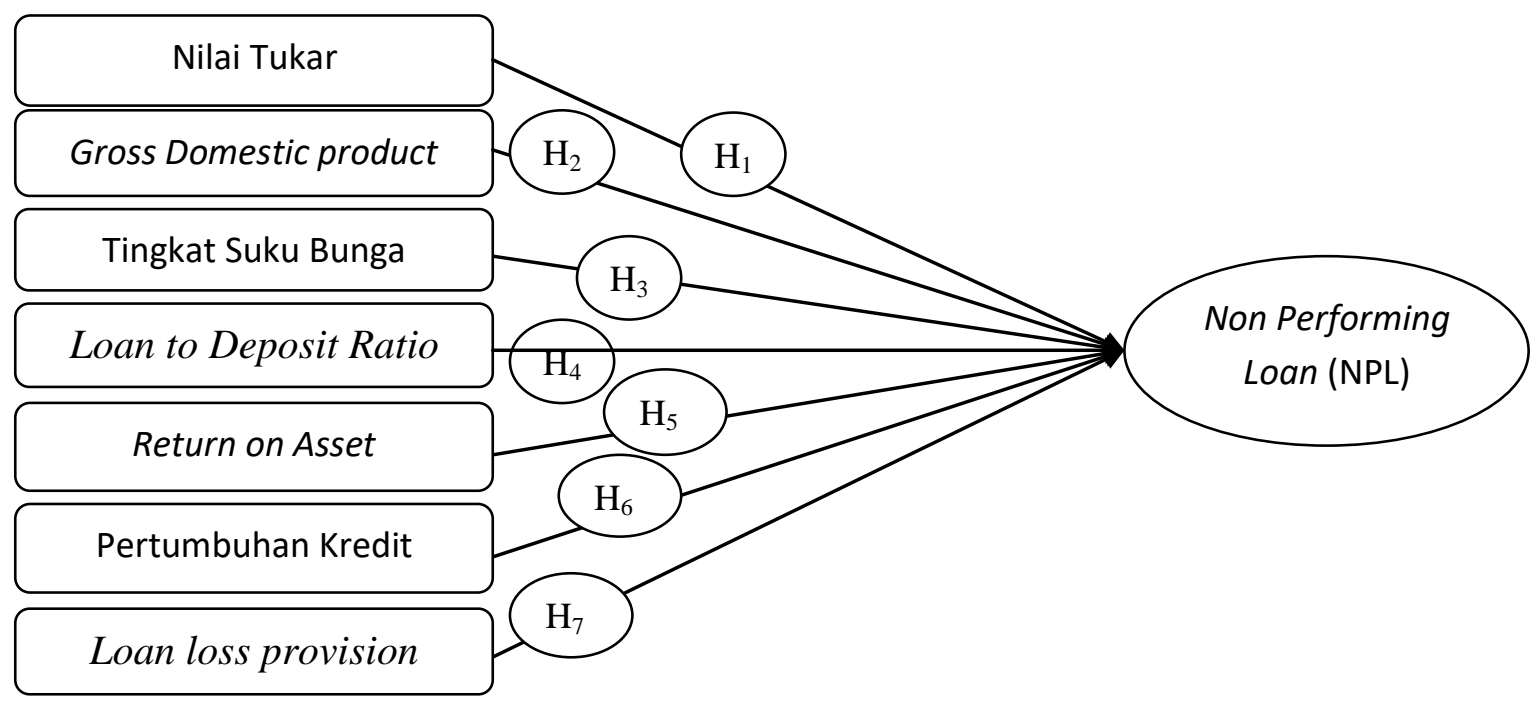

\section{METODE PENELITIAN Populasi}

Populasi dalam penelitian ini adalah seluruh bank umum swasta nasional devisa yang terdaftar di bursa efek Indonesia periode 2012 sampai 2016 yang berjumlah 44 . Teknik pengambilan sampel dalam penelitian ini dengan cara non probabilitas dengan menggunakan metode purposive sampling, sehingga sampel yang terpilih dalam penelitian ini berjumlah 10 bank.

\section{JENIS DAN SUMBER DATA}

Jenis data yang digunakan dalam penelitian ini adalah data kuantitatif. Dalam penelitian ini data yang digunakan adalah data panel /pooled data, yaitu gabungan antara data time series dan data cross setion.

Sumber data yang digunakan dalam penelitian ini adalah data sekunder. Data yang digunakan dalam penelitian diperoleh dari indonesian capital market directory (ICMD), indonesia stock exchange (IDX), otoritas jasa keuangan (OJK), direktori perbankan Indonesia, badan pusat statistik.

\section{ANALISIS DATA}

Teknik analisis data yang digunakan dalam penelitian ini adalah menggunakan regresi data panel dengan bantuan program eviews 9, dengan model persamaan regresi data panel adalah sebagai berikut:

$Y=\beta_{0}+b_{1} X_{1 i-t}+b_{2} X_{2 i-t}+b_{3} X_{3 i-t}+b_{4} X_{4}$ i-t $+b$ ${ }_{5} X_{5 i-t}+b_{6} X_{6 i-t}+b_{7} X_{7 i-t}+e_{i-t}$

Widarjono (2013)

Keterangan:

$\mathrm{Y} \quad=$ Variabel dependen (NPL)

$\mathrm{X}=$ Variabel independen

$\beta_{0} \quad=$ konstanta

$\mathrm{b}_{1}-\mathrm{b}_{7}=$ koefisien regresi

$\mathrm{X}_{1}=$ Nilai tukar pada unit i pada periode

$\mathrm{X}_{2} \quad=$ GDP pada unit i pada periode

$\mathrm{X}_{3} \quad=$ Tingkat suku bunga (BI rate) pada unit $\mathrm{i}$ pada periode $\mathrm{t}$

$\mathrm{X}_{4} \quad=$ LDR pada unit $\mathrm{i}$ pada periode $\mathrm{t}$

$\mathrm{X}_{5} \quad=$ ROA pada unit $\mathrm{i}$ pada periode $\mathrm{t}$

$\mathrm{X}_{6}=$ Pertumbuhan kredit pada unit $\mathrm{i}$ pada periode $\mathrm{t}$

$\mathrm{X}_{7} \quad=$ Loan loss provision (LLP) pada unit i pada periode $\mathrm{t}$

$\mathrm{e}=$ error term pada unit $\mathrm{i}$ pada periode $\mathrm{t}$ 


\section{HASIL PENELITIAN DAN PEMBAHASAN}

\subsection{Uji Asumsi Klasik}

\subsubsection{Uji Normalitas}
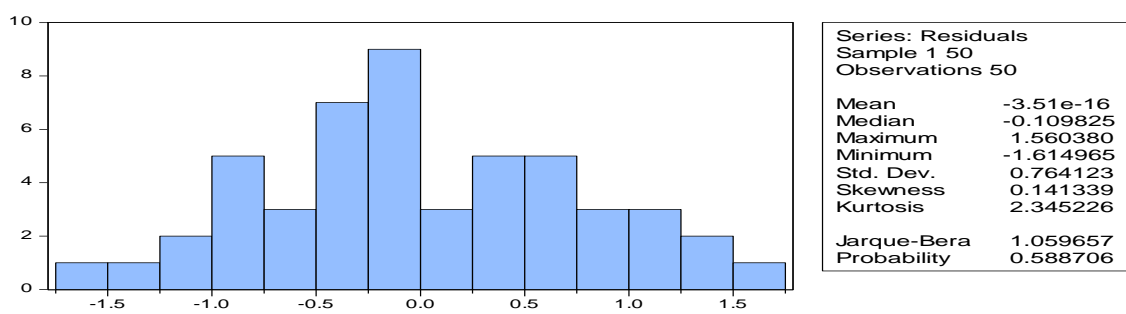

Sumber: hasil output eviews 9

Berdasarkan tabel di atas dapat disimpulkan bahwa 50 data digunakan dalam penelitian ini mempunyai nilai jarque-bera sebesar $1,059<2$ dan mempunyai probabilitas sebesar 0,58>0,05 dengan demikian dapat disimpulkan bahwa data dari variabel dalam penelitian ini telah terdistribusi normal.

\subsubsection{Uji Multikolinearitas}

\begin{tabular}{|c|c|c|c|c|c|c|c|c|}
\hline \multicolumn{1}{|c|}{ GDP } & IR & \multicolumn{1}{c|}{ LDR } & \multicolumn{1}{|c|}{ ROA } & \multicolumn{1}{|c|}{ LOANS } & \multicolumn{1}{|c|}{ Correlation } \\
\hline ER & 1.000000 & -0.945868 & 0.485768 & 0.102186 & -0.163077 & -0.268969 & 0.262482 & \\
\hline GDP & -0.945868 & 1.000000 & -0.699957 & -0.120092 & 0.145736 & 0.200757 & -0.153129 & \\
\hline IR & 0.485768 & -0.699957 & 1.000000 & 0.140836 & -0.023852 & 0.047683 & -0.151011 & \\
\hline LDR & 0.102186 & -0.120092 & 0.140836 & 1.000000 & -0.375387 & 0.271408 & -0.051150 & \\
\hline ROA & -0.163077 & 0.145736 & -0.023852 & -0.375387 & 1.000000 & -0.149114 & 0.015864 & \\
\hline LOANS & -0.268969 & 0.200757 & 0.047683 & 0.271408 & -0.149114 & 1.000000 & -0.334928 & \\
\hline LLP & 0.262482 & -0.153129 & -0.151011 & -0.051150 & 0.015864 & -0.334928 & 1.000000 & \\
\hline
\end{tabular}

Sumber: hasil output eviews 9

Berdasarkan table di atas dapat disimpulkan bahwa 50 data yang digunakan dalam penelitian ini memperlihatkan bahwa tidak terdapat hubungan variabel bebas dengan nilai lebih dari 0,8. Sehingga dapat disimpulkan bahwa data variabel dalam penelitian ini tidak mengalami multikolinearitas.

\subsubsection{Uji Autokorelasi}

Breusch-Godfrey Serial Correlation LM Test:

\begin{tabular}{ll|lll}
\hline \hline F-statistic & 0.72443 & 3 & Prob. F(2,39) & 0.4910 \\
Obs*R-squared & 1.75516 & 5 & Prob. Chi-Square(2) & 0.4158 \\
\hline \hline
\end{tabular}

Sumber: hasil output eviews 9

Berdasarkan tabel di atas merupakan hasil regresi setelah dilakukan metode transformasi terhadap persamaan pengujian autokorelasi dengan menggunakan uji breuschgodfrey (BG). Nilai probability obs*R-squared adalah 0,4158 lebih besar dari 0,05 . Sehingga dapat disimpulkan data dalam variabel penelitian ini tidak terdapat autokeralasi. 


\subsubsection{Uji heterokedastisitas}

\begin{tabular}{|llll|}
\hline Heteroskedasticity Test: White & & \\
\hline F-statistic & 3.075145 & Prob. F(30,19) & 0.0064 \\
Obs ${ }^{*}$ R-squared & 41.46101 & Prob. Chi-Square(30) & 0.0795 \\
Scaled explained SS & 19.67722 & Prob. Chi-Square(30) & 0.9247 \\
\hline \hline
\end{tabular}

Sumber: hasil output eviews 9

Berdasarkan tabel 4.6 di atas dapat disimpulkan bahwa 50 data yang digunakan dalam penelitian ini memperlihatkan bahwa pengujian heteroskedastisitas yang dilakukan dengan uji white dapat dilihat bahwa probability obs*R-squared sebesar 0,0795 lebih besar dari 0,05. Sehingga dapat disimpulkan data dalam variabel penelitian ini tidak terdapat heteroskedastisitas atau data bersifat homoskedastisitas.

\subsection{Pemilihan Model (Teknik Estimasi) Regresi Data Panel.}

\subsubsection{Uji Chow}

\begin{tabular}{|lrrr|}
\hline \hline Effects Test & Statistic & d.f. & Prob. \\
\hline \hline Cross-section $\mathrm{F}$ & 2.833844 & $(9,33)$ & 0.0139 \\
Cross-section Chi-square & 28.629891 & 9 & 0.0007 \\
\hline \hline
\end{tabular}

Sumber: hasil output eviews 9

Dari hasil pengujian chow dapat dilihat pada tabel 4.7, probabilitas cross section $\mathrm{F}$ sebesar 0,0138 dimana hasil probabilitas cross section $\mathrm{F}<0,05$ maka Ho ditolak dan Ha diterima sehingga dapat disimpulkan model yang tepat adalah model fixed effect.

\subsubsection{Uji Hausman}

\begin{tabular}{|lrrc|}
\hline \hline Test Summary & Chi-Sq. Statistic & Chi-Sq. df. & Prob \\
\hline \hline Cross-section random & 0.000000 & 7 & 1.000 \\
\hline \hline
\end{tabular}

Sumber: hasil output eviews 9

Dari hasil pengujian hausman dapat dilihat pada tabel 4.8. Nilai probabilitas $1,00>$ 0,05 maka Ho ditolak dan $\mathrm{Ha}$ diterima sehingga dapat disimpulkan model yang tepat adalah model random effect.
Dari dua uji model dapat disimpulkan bahwa model random effect lebih baik dan tepat digunakan dalam penelitian ini dari pada model common effect dan fixed effect.

\subsection{Uji Kelayakan (Goodness of Fit) Model Random Effect}

4.3.1 Koefisien Determinasi $\left(\mathrm{R}^{2}\right)$

\begin{tabular}{|llll|}
\hline \hline & \multicolumn{3}{l}{ Weighted Statistics } \\
\hline \hline R-squared & 0.706617 & Mean dependent var & 1.072751 \\
Adjusted R-squared & 0.657720 & S.D. dependent var & 1.179161 \\
S.E. of regression & 0.689865 & Sum squared resid & 19.98835 \\
F-statistic & 14.45110 & Durbin-Watson stat & 1.315096 \\
Prob(F-statistic) & 0.000000 & & \\
\hline \hline
\end{tabular}

Sumber: hasil output eviews 9

Berdasarkan table diatas, nilai mampu menjelaskan variabel terikat sebesar koefisien $\mathrm{R}^{2}$ sebesar 0,706616 atau $70,66 \%$. 70,66\%, sedangkan sisanya $(29,34 \%)$ Artinya variabel bebas dalam model regresi dipengaruhi oleh variabel lain di luar model. 


\subsubsection{Uji Simultan (F test)}

\begin{tabular}{|llll|}
\hline \hline \multicolumn{3}{l|}{ Weighted Statistics } \\
\hline \hline R-squared & 0.706617 & Mean dependent var & 1.072751 \\
Adjusted R-squared & 0.657720 & S.D. dependent var & 1.179161 \\
S.E. of regression & 0.689865 & Sum squared resid & 19.98835 \\
F-statistic & 14.45110 & Durbin-Watson stat & 1.315096 \\
Prob(F-statistic) & 0.000000 & & \\
\hline \hline
\end{tabular}

Sumber: hasil output eviews 9

Hasil uji $\mathrm{F}$ pada penelitian ini memiliki nilai koefisien sebesar 14,45110 dengan prob (F statistik) sebesar $0,000000<0,05$. Maka $\mathrm{H}_{0}$ ditolak dan Ha diterima. Hasil ini memiliki arti bahwa variabel bebas (nilai tukar, GDP, tingkat suku bunga (BI rate), LDR, ROA, pertumbuhan kredit, LLP) secara simultan mempunyai pengaruh secara signifikan terhadap non performing loan.

\subsubsection{Uji Parsial (t test)}

\begin{tabular}{|c|c|c|l|}
\hline \multicolumn{3}{|c|}{ Hasil Regresi } \\
\hline Variabel & Coefficient & Prob. & \multicolumn{1}{c|}{ Hasil Regresi } \\
\hline ER & 0,000484 & 0,1229 & Berpengaruh positif tidak signifikan \\
\hline GDP & 1,550263 & 0,2524 & Berpengaruh positif tidak signifikan \\
\hline IR & 0,106337 & 0,0229 & Berpengaruh positif signifikan \\
\hline LDR & $-0,005207$ & 0,7285 & Berpengaruh negatif tidak signifikan \\
\hline ROA & $-0,597174$ & 0,0001 & Berpengaruh negatif signifikan \\
\hline LOANS & $-0,015459$ & 0,0488 & Berpengaruh negatif signifikan \\
\hline LLP & 0,812547 & 0,0009 & Berpengaruh positif signifikan \\
\hline
\end{tabular}

Sumber: hasil olahan, eviews 9

Berdasarkan hasil analisis regresi pada tabel diatas diketahui bahwa nilai probabilitas variabel nilai tukar (ER) sebesar 0,1229 yang lebih besar jika dibandingkan dengan $(\alpha)=$ 0,05 maka H0 diterima. Hal ini berarti secara statistik nilai tukar (ER) tidak memiliki pengaruh signifikan terhadap NPL.

Berdasarkan hasil analisis regresi pada tabel diatas diketahui bahwa nilai probabilitas variabel gross domestic product suku bunga (BI rate) memiliki pengaruh signifikan terhadap NPL.

Berdasarkan hasil analisis regresi pada tabel diatas diketahui bahwa nilai probabilitas variabel loan to deposit ratio (LDR) sebesar 0,7285 yang lebih besar jika dibandingkan dengan $(\alpha)=0,05$ maka $\mathrm{H} 0$ diterima. Hal ini berarti secara statistik loan to deposit ratio (LDR) tidak memiliki pengaruh signifikan terhadap NPL.

Berdasarkan hasil analisis regresi pada tabel diatas diketahui bahwa nilai probabilitas variabel return on asset sebesar
(GDP) sebesar 0,2542 yang lebih besar jika dibandingkan dengan $(\alpha)=0,05$ maka H0 diterima. Hal ini berarti secara statistik gross domestic product (GDP) tidak memiliki pengaruh signifikan terhadap NPL.

Berdasarkan hasil analisis regresi pada tabel diatas diketahui bahwa nilai probabilitas variabel tingkat suku bunga (BI rate) sebesar 0,0229 yang lebih kecil jika dibandingkan dengan $(\alpha)=0,05$ maka H0 ditolak. Hal ini berarti secara statistik tingkat 0,0001 yang lebih kecil jika dibandingkan dengan $(\alpha)=0,05$ maka H0 ditolak. Hal ini berarti secara statistik return on asset memiliki pengaruh signifikan terhadap NPL.

Berdasarkan hasil analisis regresi pada table diatas diketahui bahwa nilai probabilitas variabel pertumbuhan kredit (LOANS) sebesar 0,0488 yang lebih kecil jika dibandingkan dengan $(\alpha)=0,05$ maka $\mathrm{H} 0$ dolak. Hal ini berarti secara statistik pertumbuhan kredit memiliki pengaruh signifikan terhadap NPL. 
Berdasarkan hasil analisis regresi pada tabel diatas diketahui bahwa nilai probabilitas variabel loan loss provision (LLP) sebesar 0,0488 yang lebih kecil jika dibandingkan dengan $(\alpha)=0,05$ maka $\mathrm{H} 0$ diterima. Hal ini berarti secara statistik loan loss provision memiliki pengaruh signifikan terhadap NPL.

\section{PEMBAHASAN}

Nilai tukar berpengaruh positif terhadap non performing loan (NPL)

Hasil yang diperoleh pada pengujian hipotesis pertama sejalan dengan penelitian Linda et al. (2015) yang menemukan bahwa kurs tidak berpengaruh signifikan terhadap non performing loan yang dimiliki oleh sebuah bank, karena perubahan nilai tukar tidak begitu dirasakan oleh nasabah, keadaan tersebut terjadi karena perubahan kurs yang relatif terjadi dalam jangka pendek, sehingga situasi tersebut tidak begitu mengganggu bisnis yang dijalankan nasabah oleh sebab itu perubahan nilai tukar rupiah tidak mempengaruhi kemampuan nasabah untuk membayar tagihan kredit. Perubahan nilai tukar yang terjadi hanya mempengaruhi besaran harga produk yang hendak dibeli oleh nasabah diawal transaksi saja. Fenomena tersebut mendorong rasio kredit bermasalah yang diukur dengan non performing loan tidak mengalami perubahan berarti akibat adanya perubahan kurs.

\section{GDP berpengaruh negatif terhadap non performing loan (NPL)}

Variabel GDP memberikan hasil estimasi tanda koefisien yang positif tidak sesuai dengan hipotesis awal penelitian. Hasil t-test menunjukkan bahwa variabel GDP tidak memiliki pengaruh yang signifikan terhadap NPL. Meningkatnya GDP menunjukkan adanya peningkatan aktivitas ekonomi membuat pendapatan masyarakat akan meningkat sehingga masyarakat bisa memenuhi kewajibannya dan resiko terjadinya kredit bermasalah akan mengalami penurunan dapat dikatakan jika peningkatan GDP akan menurunkan terjadinya NPL. Hal ini dapat terjadi karena dengan adanya kenaikan pertumbuhan ekonomi yang menunjukkan bahwa semua bidang usaha dalam kondisi baik yang ditandai dengan peningkatan produktivitas. Pada saat pertumbuhan mengalami kenaikan biasanya kegiatan usaha juga akan menguntungkan sehingga pendapatan yang diterima masyarakat meningkat.

Tingkat suku bunga berpengaruh positif terhadap non performing loan (NPL)

Hasil t-test menunjukkan bahwa variabel tingkat suku bunga memiliki pengaruh yang signifikan terhadap NPL. Artinya semakin tinggi tingkat suku bunga pinjaman maka semakin tinggi tingkat NPL karena pihak nasabah tidak dapat membayar kewajibannya dengan tepat waktu. Peningkatan suku bunga memperburuk kualitas dari pinjaman semakin tingginya bunga kredit membuat debitur semakin sulit membayarkan pinjamannya. Dengan demikian dapat diartikan bahwa semakin tinggi bunga yang dibebankan kepada debitur maka kemungkinan besar akan meningkatkan kredit bermasalah.

Loan to deposit ratio (LDR) berpengaruh positif terhadap non performing loan (NPL)

Hasil t-test menunjukkan bahwa variabel LDR tidak memiliki pengaruh yang signifikan terhadap NPL. Meskipun pengaruhnya tidak signifikan. namun hubungan negatif yang terjadi antara LDR dengan NPL tersebut sesuai dengan teori intermediasi perbankan. Rasio LDR yang berada pada kisaran terbaik yang ditentukan Bank Indonesia menunjukkan bahwa bank yang bersangkutan telah berhasil menjalankan fungsi intermediasinya yaitu funding dan lending dengan baik. Ketika LDR terlalu rendah. dana yang berhasil dihimpun bank belum dimanfaatkan secara optimal dalam bentuk penyaluran kredit, sehingga pendapatan bunga yang diterima pun lebih sedikit. Jika tujuan manajemen perusahaan adalah mengejar laba. maka strategi menaikkan suku bunga kredit akan dipilih dan pada akhirnya meningkatkan potensi debitur gagal bayar. Penyaluran kredit yang tinggi diharapkan akan mampu menekan rasio NPL.

Return on asset (ROA) berpengaruh negatif
terhadap non performing loan (NPL)
Hasil t-test menunjukkan bahwa
variabel ROA memiliki pengaruh yang
signifikan terhadap NPL. ROA merupakan
efisiensi dalam pemanfaatan aset dan
menunjukkan seberapa besar pendapatan yang
dihasilkan dari asset. Hal ini juga sesuai


dengan hipotesis "bad management" pada penelitian Berger deYoung (1997) yang mengatakan bahwa praktik manajemen yang buruk akan berdampak pada laba mereka akibat persoalan efisiensi biaya yang dikeluarkan perusahaan serta kualitas kredit yang diberikan pada debitur. Praktik manajemen yang buruk tersebut dikarenakan para manajer yang tidak kompeten dalam menjalankan berbagai kegiatannya. Ketika mereka tidak memiliki keterampilan yang cukup dalam hal credit scoring. menilai agunan hingga pengawasan terhadap debitur, faktor-faktor kesalahan manajemen tersebut akhirnya meningkatkan NPL.

Pertumbuhan kredit berpengaruh positif terhadap non performing loan (NPL)

Hasil t-test menunjukkan bahwa variabel pertumbuhan kredit memiliki pengaruh yang signifikan terhadap NPL. Keeton (1999) dalam Ghosh (2015) menyatakan bahwa semakin cepat pertumbuhan kredit sebenarnya akan berimplikasi peningkatan kerugian kredit. Hal ini dapat pula terjadi karena ketika bank meningkatkan penawaran kreditnya bank mencoba memberikan kelonggaran mengenai standar kredit atau melakukan berbagai kecurangan lainnya sehingga meskipun terkesan bank mampu menjalankan fungsi intermediasinya dengan baik karena kreditnya banyak tersalurkan namun debitur yang tidak kompeten hanya akan membawa masalah kredit macet bagi bank yang bersangkutan.

Pada faktanya. berdasarkan hasil pengujian penelitian kali ini asumsi tersebut tidak dapat dibuktikan. Justru hal sebaliknya yang berlaku bahwa pertumbuhan kredit dengan asumsi penyaluran kredit selektif akan menurunkan tingkat kredit bermasalah sehingga hubungannya menjadi negatif. Semakin besar tingkat pertumbuhan kredit maka rasio NPL akan berkurang.

\section{Loan loss provision (LLP) berpengaruh positif terhadap non performing loan (NPL)}

Hasil t-test menunjukkan bahwa variabel LLP memiliki pengaruh yang signifikan terhadap NPL. Abid. et al (2014) menghubungkan variabel kualitas kredit ini ke dalam hipotesis "skimping" milik Berger de Young (1997). Dalam hal ini meningkatnya CKPN kredit sebagai hasil estimasi besarnya risiko kredit yang meningkat akan membuat bank melakukan berbagai penghematan untuk menekan biaya operasional lainnya. Penghematan yang dilakukan para manager demi terlihat efisien justru akan menimbulkan masalah jangka panjang. Terkait dengan penghematan biaya aktivitas pengkreditan semakin biaya tersebut ditekan maka bisa menjadikan kualitas kredit tersebut menurun pada akhirnya kualitas kredit yang rendah akan meningkatkan NPL. Selain itu meningkatnya LLP akan mengurangi laba bersih dari bank yang bersangkutan. Kebijakan menaikkan margin tentu akan dipertimbangkan meskipun pada akhirnya dapat meningkatkan peluang terjadinya kredit bermasalah yang lebih besar.

\section{KESIMPULAN DAN SARAN}

\subsection{Kesimpulan}

Nilai tukar (ER) berpengaruh positif tidak signifikan terhadap NPL, gross domestic product (GDP) berpengaruh positif tidak signifikan terhadap NPL, tingkat suku bunga (BI rate) berpengaruh positif signifikan terhadap NPL, loan to deposit ratio (LDR ) berpengaruh negatif tidak signifikan terhadap NPL, return on asset (ROA) berpengaruh negatif signifikan terhadap NPL, pertumbuhan kredit (LOANS) berpengaruh negatif signifikan terhadap NPL, loan loss provision (LLP) berpengaruh positif signifikan terhadap NPL.

\subsection{Keterbatasan Penelitian}

1. Sampel yang digunakan dalam penelitian ini terbatas pada 10 bank saja (bank umum swasta nasional devisa)

2. Penelitian ini menggunakan data tahunan dengan demikian dalam penelitian ini tidak dapat menangkap peristiwa-peristiwa penting dalam bulanan, kuartalan dan semesteran yang berdampak pada efisiensi dan risiko bank.

5.3 Saran

Untuk penelitian selanjutnya disarankan tetap menggunakan variabel dalam penelitian ini dan menambahkan variabel makro ekonomi yaitu income per kapita dan variabel fundamental yaitu CAR. 


\section{DAFTAR PUSTAKA}

Abid, Lobna, Ouertani, M., N \& Ghorbel, S., Z. 2014. "Macroeconomic and Bank- Specific Determinants of Household's Non-Performing Loans in Tunisia. Journal of Economics and Finance Vol. 13 p. $58-68$.

Achmadi, M.Uzahir. 2014. "Pengaruh CAR, BOPO, ROA, terhadap Non Performing Loans Bank Nasional. "Media Bisnis. Volume 6, Nomor 1.

Ahmad, F. \& Bashir, T. 2013. “Explanatory Power of Bank Specific Variables as Determinants of Non-Performing Loans: Evidence from Pakistan Banking Sector". World Applied Sciences Journal: Pakistan 22 (9): 12201231. IDOSI Publications.

Andres, Carlos \& Olaya Bonilla. 2012. "Macroeconomic Determinants of the Non-Performing Loans in Spain and Italy."

Astrini, Km Suli, I Wayan Sawendra \& I Ketut Suwarna. 2014. Pengaruh CAR, LDR, Dan Bank Size Terhadap NPL Pada Lembaga Perbankan Yang Terdaftar Di Bursa Efek Indonesia. E-Journal Bisma Universitas Pendidikan Ganesha. Vol. 2, diakses 2 Desember 2015.

Badar, Munib, Atiya Yasmin Javid \& Shaheed Zulfiquar. 2013. Impact of Macro economic forces on Nonperforming loans an empirical study. Elixir International Journal

Barus, A. C. \& Erick. 2016. Analisis FaktorFaktor yang Mempengaruhi Non Performing Loan pada Bank Umum di Indonesia. Jurnal Wira Ekonomi Mikroskil. Volume 6, Nomor 02
Beck, Roland, Jakubik, P.\& Piloiu. 2013.” Non performing loans What matters in Addition to the Economic Cycle?." Working Paper Series.

Berger A. N. \& R. DeYoung. (1997). "Problem loans and cost efficiency in commercial banks." Journal of Banking and Finance, vol. 21, pp. 849-870.

Djohanputro, B., \& Kountur, R. 2007. Non Performing Loans Bank Perkreditan Rakyat. Laporan Penelitian. Bank Indonesia- GTZ

Bofondi, M., Ropele, T. 2011. Macroeconomic determinants of bad loans: evidence from Italian banks. Occasional Papers, 89.

Dendawijaya, Lukman. 2005. Manajemen Perbankan: edisi Kedua, Cetakan Kedua, Ghalia Indonesia. Bogor Jakarta.

Fahmi, Irham .2011."Analisis Laporan Keuangan." Bandung : Alfabeta

Ghosh, Amith, 2015. "Banking-industry specific and regional economic determinants of non performing loans: Evidence from US states". Journal of Financial Stability Vol.20. p 93- 104.

Hanafi, M.M. 2009. Manajemen Risiko: Edisi Kedua. Yogyakarta : Unit Penerbit dan Percetakan Sekolah Tinggi Ilmu Manajemen YKPN.

Hasibuhan, Malayu. 2005. Dasar-Dasar Perbankan. Jakarta: PT. Bumi Aksara.

Kasmir. 2014." Dasar Dasar Perbankan: Edisi Revisi 2008. Jakarta: PT Raja Grafindo Persada.

2008. Analisis Laporan Keuangan.

Raja Grafindo Persada. Jakarta.

Khemraj, T., Pasha, S. 2009. The determinants of non-performing loans: An 
econometric case study of Guyana. The Caribbean Centre for Banking and Finance Biannual Conference on Banking and Finance, St. Augustine, Trinidad.

Kuncoro, Mudrajad \& Suhardjono. 2002. Manajemen Perbankan. Teori dan Aplikasi. Yogyakarta: BPFE.

Linda, Mukthia, Roza. 2015. Pengaruh Inflasi, Kurs dan Tingkat Suku Bunga terhadap Non Performing Loan pada PT. Bank Tabungan Negara Tbk Cabang Padang. Journal of Economic and Economic Education Vol.3 No.2 (137-144).

Mada, R.P \& Arfinto, E. D. 2015. Analisis Faktor-Faktor yang Mempengaruhi Non Performing Loans di Indonesia (Studi Pada Bank Umum Konvensional yang Terdaftar di Bank Indonesia Tahun 2011-2014). Diponegoro Journal of Management. Volume 4, Nomor 3.

Mahmoeddin, As. 2010. Melacak Kredit Bermasalah:Cetakan Pertama. Jakarta: Pustaka Sinar Harapan.

Mankiw, N. Gregory. 2000. Teori Makro Ekonomi. Edisi Keempat. Jakarta: Erlangga.

McEachern, William. 2000. Ekonomi Makro: Pendekatan Kontemporer. Jakarta: Salemba Empat.

Messai, Ahlem, S, \& Fathi, Jouni. 2013. "Micro and Macro Determinants of Nonperforming Loans. "International Journal of Economics and Financial Issues, 3(4): $852-860$.

Ozili, P.K. 2015. "How Managers Anticipate Non-Performing Loans : Evidence From U.S, Europe, Asia and Africa. Red Fame
Publishing Finance and Accounting, Vol.1 No.2.

Roslita, Maya \& Musdolifah. 2016."Pengaruh Makroekonomi, Capital Adequacy Ratio, Loan To Deposit Ratio Dan Pertumbuhan Kredit Terhadap Non Performing Loan Pada Bank Asing Di Indonesia Periode 2013-2014." Jurnal Ilmu Manajemen. Volume 4, Nomor 2

Simorangkir. 2004. Pengantar Lembaga Keuangan Bank dan Non Bank. Bogor: Ghalia Indonesia.

Sukirno, Sadono. 1994. Pengantar Teori Ekonomi Makro. Jakarta : Penerbit Raja Grafindo.

Syamsuddin, Lukman. (2009). Manajemen Keuangan Perusahaan: Konsep Aplikasi ing Planning, Supervision, lan Making Decision (New Edition). Jakarta: PT. Raja Grafindo Persada.

Soebagio, Hermawan. 2005. Analisis FaktorFaktor Yang Mempengaruhi Terjadinya Non Performing Loan (NPL) Bank Umum Komersial. Tesis Dipublikasikan. Tesis Prodi Sains Akuntansi Program Pasca Sarjana Universitas Diponegoro.

Utari, G A Diah, Trinil Arimurti \& Ina Nurmalia Kurniati. 2012. Pertumbuhan Kredit Optimal. Buletin Ekonomi Moneter dan Perbankan.

Washington, Gitonga Kariuki. 2014. Effect Of Macroeconomic Variables On Credit Risk In The Kenyan Banking System. International Journal of Business and Commerce (Online), Vol. 3, No. 9, Pg. 01-26.

Widarjono, Agus. 2013. Ekonometrika: Pengantar dan Aplikasinya, Ekonosia. Jakarta. 
Wolk, Harry I., et al . (2004). Accounting Theory Conceptual Issues in a Political and Economic Environment Sixth Edition. Ohio: Thomson Learning.

Yulita, Anatia. 2014. Analisis Pengaruh Faktor Makroekonomi Terhadap
Tingkat Kredit Bermasalah Pada Bank Umum Di Indonesia. Skripsi Jurusan Manajemen Program Sarjana Universitas Diponegoro. 
